Article

\title{
Techno-Economic Analysis and Physicochemical Properties of Ceiba pentandra as Second-Generation Biodiesel Based on ASTM D6751 and EN 14214
}

\author{
N.A.M. Jamaluddin ${ }^{1}$, Teuku Meurah Indra Riayatsyah ${ }^{2}$, Arridina Susan Silitonga ${ }^{3, *}{ }^{\mathbb{C}}$, \\ M. Mofijur ${ }^{4}$, Abd Halim Shamsuddin 1, Hwai Chyuan Ong 4,5,*D, \\ Teuku Meurah Indra Mahlia ${ }^{4, *(D)}$ and S.M. Ashrafur Rahman ${ }^{6}$ \\ 1 Institute of Sustainable Energy, Universiti Tenaga Nasional, Kajang 43000, Selangor, Malaysia \\ 2 Department of Mechanical Engineering, Syiah Kuala University, Banda Aceh 23111, Indonesia \\ 3 Department of Mechanical Engineering, Politeknik Negeri Medan, 20155 Medan, Indonesia \\ 4 School of Information, Systems and Modelling, Faculty of Engineering and Information Technology, \\ University of Technology Sydney, NSW 2007, Australia \\ 5 Department of Mechanical Engineering, Faculty of Engineering, University of Malaya, \\ Kuala Lumpur 50603, Malaysia \\ 6 Biofuel Engine Research Facility (BERF), Queensland University of Technology, Brisbane QLD 4000, Australia \\ * Correspondence: ardinsu@yahoo.co.id (A.S.S.); ong1983@yahoo.com (H.C.O.); \\ TMIndra.Mahlia@uts.edu.au (T.M.I.M.)
}

Received: 6 August 2019; Accepted: 13 September 2019; Published: 19 September 2019

\begin{abstract}
Processing biodiesel from non-edible sources of feedstock seems to be thriving in recent years. It also has also gathered more attention than in the past, mainly because the biodiesel product is renewable and emits lower pollution compared to fossil fuels. Researchers have started their work on various kinds of biodiesel product, especially from a non-edible feedstock. Non-edible feedstocks such as Ceiba pentandra show great potential in the production of biodiesel, especially in the Southeast Asia region because the plants seem to be abundant in that region. Ceiba pentandra, also known as the Kapok tree, produces hundreds of pods with a length of $15 \mathrm{~cm}$ (5.9 in) and diameter $2-5 \mathrm{~cm}$ (1-2 in). The pods consist of seeds and fluff in the surrounding areas inside the pod, which itself contains yellowish fibre, a mixture of cellulose and lignin. The seeds of Ceiba pentandra can be used as feedstock for biodiesel production. The study for Ceiba pentandra will involve techno-economic, as well as a sensitivity analysis. Moreover, the study also shows that the techno-economic analysis of a biodiesel processing plant for 50 ktons Ceiba pentandra with a life span of 20 years is around $\$ 701$ million with 3.7 years of the payback period. Besides that, this study also shows the differences in operating cost and oil conversion yield, which has the least impact on running cost. By improving the conversion processes continuously and by increasing the operational efficiency, the cost of production will decrease. In addition, the study also explains the differences of final price biodiesel and diesel fossil fuel, both showing dissimilar scenarios subsidy and taxation. Biodiesel has a subsidy of $\$ 0.10 / \mathrm{L}$ and $\$ 0.18 / \mathrm{L}$ with a total tax exemption of $15 \%$. The value was obtained from the latest subsidy cost and diesel in Malaysia. Finally, further research is needed in order to fully utilize the use of Ceiba pentandra as one of the non-edible sources of biodiesel.
\end{abstract}

Keywords: techno-economic: life cycle cost; sensitivity analysis; Ceiba pentandra; non-edible oil

\section{Introduction}

Biodiesel is a clean, smouldering, renewable fuel that is usually produced from vegetable oils, animal oil or fats, waste cooking oil and tallow [1-3]. It may be determined by a chemical process 
on how the glycerine can be extracted from the vegetable or animal oil [4,5]. The main purpose of biodiesel is to replace the petroleum diesel fuel or to be mixed with petroleum diesel fuel in certain types of uses to reduce greenhouse gas emission [6-9]. Biodiesel is good for the environment because it is comprised of renewable sources that emit fewer emissions compared to petroleum diesel fuel. In Malaysia, they have already started to utilize $10 \%$ of biodiesel fuel in the transport sector and $7 \%$ in the industrial sector beginning in July 2016 [10]. In biodiesel production, there are many different feedstocks that have been used. Biodiesel can be produced by utilizing edible oils and non-edible oils as resources. In Malaysia and Indonesia, palm oil and coconut oil were commonly used as the edible feedstock in biodiesel production [11-15]. However, usage of the edible oil can result in competition between usages of food against fuel. This also can increase the condemnation of sustainable edible oils for biodiesel production [16-18]. However, many types of non-edible oils can be used as main sources of biodiesel production. This can help to reduce the cost of production, also keeping at bay the conflict of food versus fuel. Besides that, non-edible oils have a reasonable price and are easily obtainable in tropical countries. There are many types of non-edible oils that have been used as feedstock for biodiesel production. For example, from vegetable oils there are Jatropha curcas, Pongamia pinnata (Karanja), Madhuca indica (Mahua), Linseed, Cottonseed, Azadirachta indica (Neem), Camelina, Reutealis Trisperma, Calophyllum Inophyllum, Hevea Brasiliensis, Ricinus Communis, Ceiba pentandra, Schleichera Oleosa, Cerbera manghas and beauty leaf tree [19-24]. From wasted or recycled oils there are cooking oil, vegetable oil, frying oil, soap stocks and pomace oil [25-33]. Also, there are uses for animal fats such as chicken fat, beef tallow, yellow grease, pork lard and fish oil products [34-41].

Currently, there are plenty of publications discussing algae for biodiesel production. This is due to the potential of the algae in supplying enough oil for global consumption and utilization, as well as global warming caused by burning fossil fuel [42-52]. The usage of algae as non-edible oil has increased throughout the year; this is mainly because of the oil content and making it as the second generation biodiesel production [53]. Besides that, there are other feedstocks such as used vegetable oils, yellow grease, brown grease and soap stock produced from refining vegetable oils [54]. Biodiesel production cost can be reduced due to this type of feedstock being very low in price and easy to obtain. The use of cooking oil as biodiesel for biodiesel production is one of the best options of economical sources [55-59]. Biodiesel production should be focusing on non-edible sources as a way to avoid conflict with food. For that reason, as a non-edible oil, Ceiba pentandra can be used as one of the new sources for biodiesel production. Nowadays, the production rate of biodiesel from non-edible feedstock seems to be declining year after year. In order to maintain the production of biodiesel, new sources need to be discovered and a life cycle cost analysis must be conducted. Therefore, this paper will be focusing on Ceiba pentandra as the new non-edible biodiesel feedstock. The main objectives of this paper are to assess the Ceiba pentandra as a probable source for upcoming energy supply through techno-economic and sensitivity analysis.

\section{Materials and Methods}

\subsection{Materials}

Ceiba pentandra is an emergent tree of the tropical rainforests and is often described as majestic, as shown in Figure 1. Locally, it is called Kapok and is the cotton-like fluff that may derive from the seedpods. Ceiba pentandra also has many common names such as Kapok tree, Ceiba de Lana, silk-cotton tree, etc. Ceiba pentandra can be a very large tree with a trunk diameter of up to $3 \mathrm{~m}(9.8 \mathrm{ft}$.), capable of reaching $70 \mathrm{~m}(230 \mathrm{ft}$.). The main trunk and the branches are crowded with thorns around it. The kapok leaves have leaflets of around 5 to 9 , and the leaf length is around $20 \mathrm{~cm}$ (7.9 in). The Kapok tree produces hundreds of pods with a length of $15 \mathrm{~cm}$ (5.9 in) and a diameter of $2-5 \mathrm{~cm}(1-2 \mathrm{in})$. The pods consist of seeds and are fluffy in the surrounding areas inside the pod. The pod also contains yellowish fibre, which is a mixture of cellulose and lignin. What makes Ceiba pentandra different with other species are the pattern and the sizes of its conical spines [60]. 


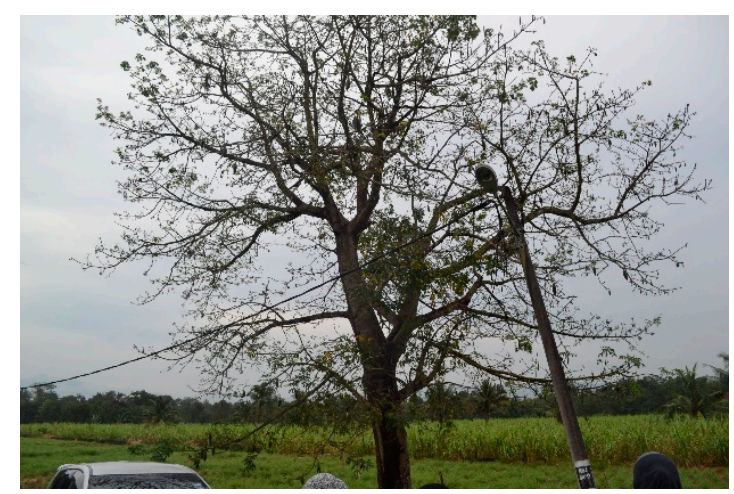

Ceiba pentandra tree

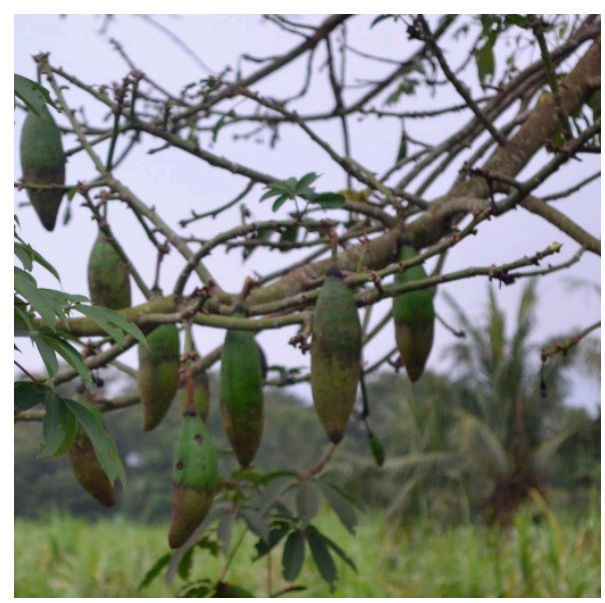

Ceiba pentandra fruits

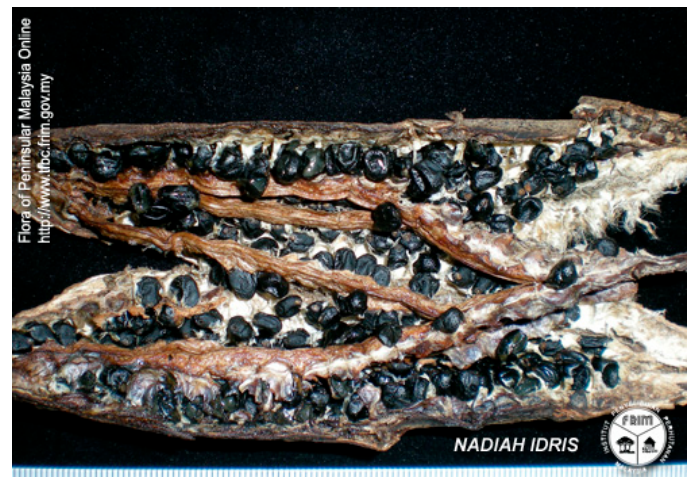

Ceiba pentandra seed within the pods

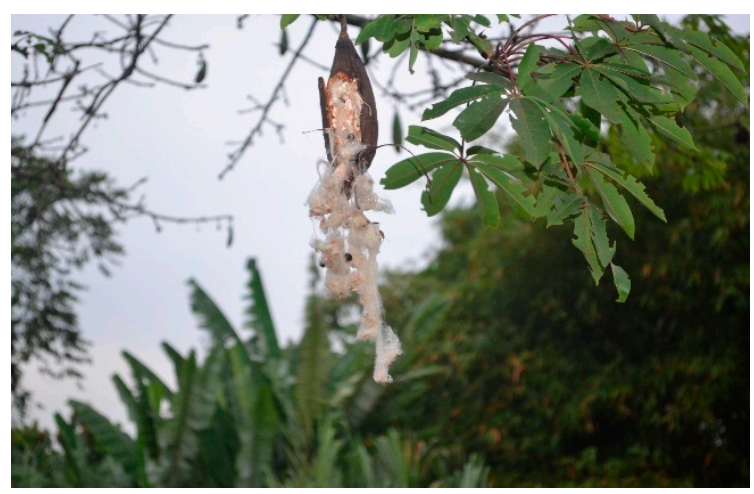

"Kapok" of Ceiba pentandra

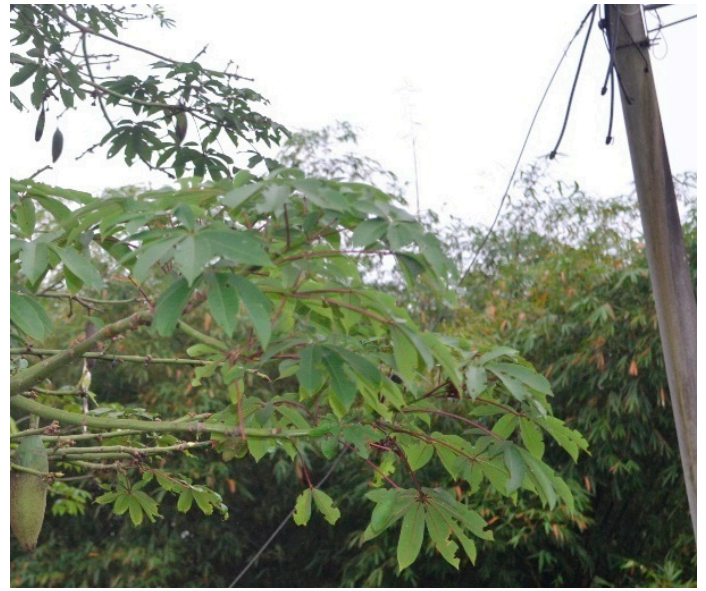

Ceiba pentandra leaves
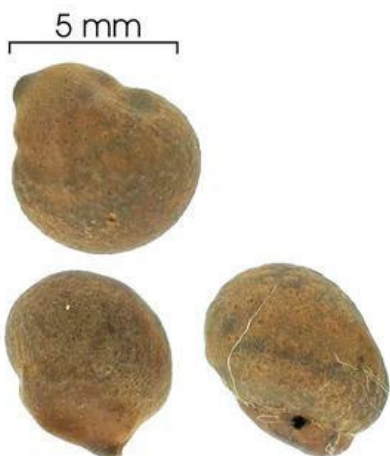

Ceiba pentandra dried seed

Figure 1. Ceiba pentandra at rural area in Malaysia.

Ceiba pentandra can be found all around the world, such as in Indonesia, Malaysia, South and Central America, Mexico, West Africa, and Caribbean islands as shown as Figure 2. 

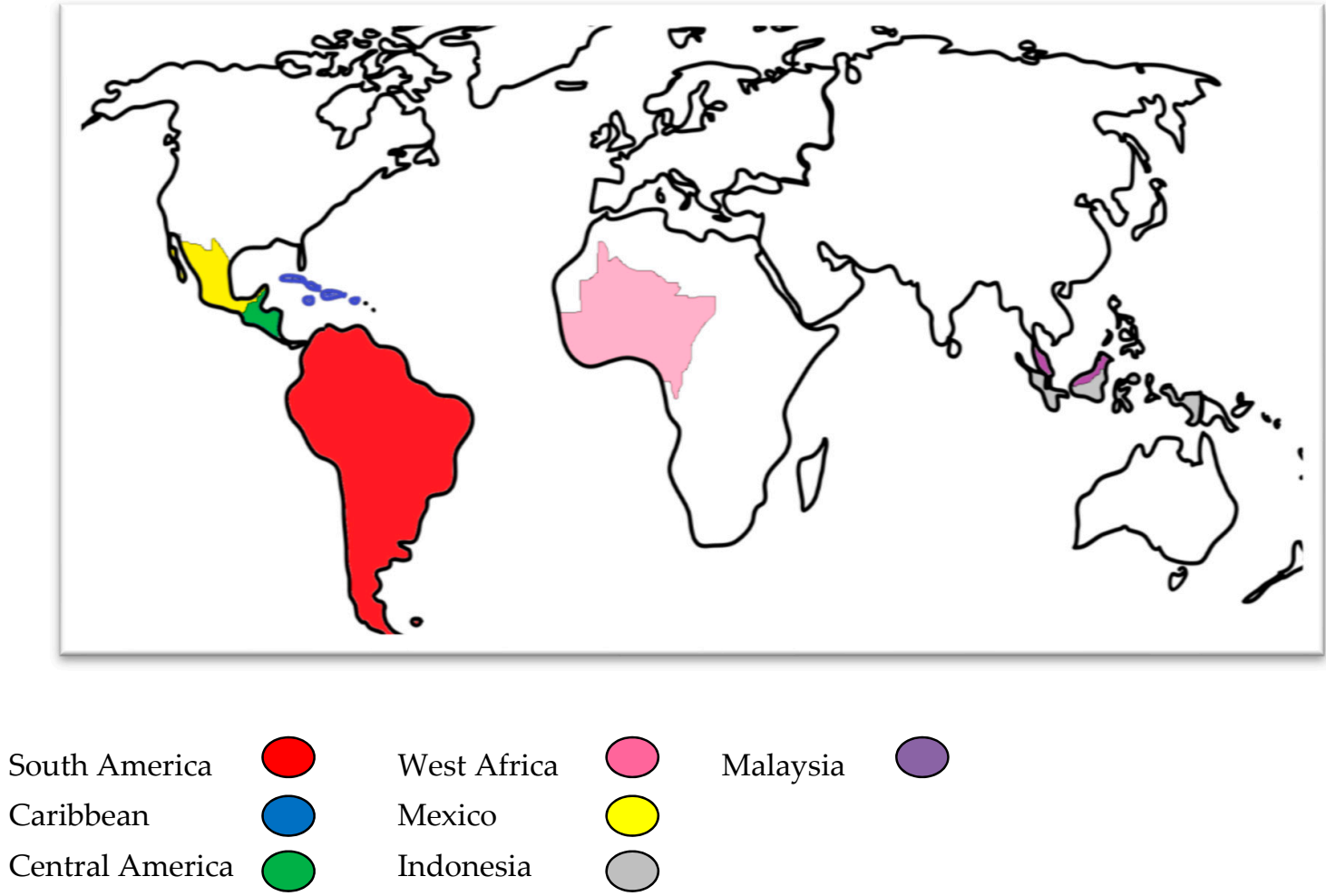

Figure 2. Worldwide location of Ceiba pentandra.

\subsection{Methods}

\subsubsection{Data Collection}

Data was collected from a variety of sources such as journal papers, conference proceedings, biodiesel production experts, research reports, and the latest market price, as well as the practitioners experienced in this field in 2019. Data collection method can be found in elsewhere [53,61]. The capital cost or initial capital cost of the installation of plants for biodiesel production is generally based on the capacity of production that will be developed.

\subsubsection{Life Cycle Cost}

The life cycle costs (LCC) also evaluate the economic benefits of the plant. In this part, the lifecycle cost of Ceiba pentandra oil for biodiesel production from renewable sources of feedstocks from tropical biodiversity is developed, and it is divided into six parameters as follows:

$$
L C C=C C+O C+M C+F C-S V-B P
$$

Recently, economics and business have widely used present value calculations to compare cash flows at a different period. Implementing this method, the model for present value for life cycle cost calculations is presented by the following equation [62]:

$$
L C C=C C+\sum_{i=1}^{n} \frac{O C_{i}+M C_{i}+F C_{i}}{(1+r)^{i}}-\frac{S V}{(1+r)^{n}}-\sum_{i=1}^{n} \frac{B P_{i}}{(1+r)^{i}}
$$

- Present worth factor

The total estimated cost of the project that currently collected from future cash flows is called the present value factor (PWF). The investigation feasibility of the biodiesel production plant is established 
by using the PWF with a selected interest rate. For the years i, PWF can be calculated by the following equation [63]:

$$
P W F=\frac{1}{(1+r)^{i}}
$$

Summing it over the life span of $n$ years produces the compound present worth factor $(C P W)$, which can be written as follows:

$$
\begin{aligned}
& C P W=\sum_{i=1}^{n} \frac{1}{(1+r)^{i}} \\
& C P W=\frac{(1+r)^{n}-1}{r(1+r)^{n}}
\end{aligned}
$$

\section{- Capital cost}

There are three categories in calculating the capital cost; namely, maximum, nominal and minimum of initial capital costs of a biofuel production plant, which is based on its production capability. These three categories to calculate the capital cost of the plant for biofuel production are determined by the following [64]:

$$
\begin{aligned}
& C C_{\text {high }}=-517.76 \times P C^{2}+252928 \times P C+3446300 \\
& C C_{\text {avg }}=-430.13 \times P C^{2}+205235 \times P C+2696000 \\
& C C_{\text {low }}=-342.49 \times P C^{2}+157542 \times P C+1945700
\end{aligned}
$$

\section{- Operating cost}

The operating costs comprise the transportation costs, factory costs, utility costs, laboratory services, supervision costs, labour costs, administrative expenses, energy flows and all other related material. The waste treatment and sewage sludge treatment is also included with the operating costs. Because production capacity is correlated with operating costs, the operating cost was determined by setting the cost per ton of biodiesel constant. Operating costs during the project period are projected as follows [63]:

$$
O C=\sum_{i=1}^{n} \frac{O R \times P C}{(1+r)^{i}}
$$

- Maintenance cost

The service cost and maintenance costs are considered to be the maintenance percentage ratios to the initial capital cost and assumed to be constant during the project life span. The total maintenance costs for the project life span can be determined as follows [63]:

$$
M C=\sum_{i=1}^{n} \frac{M R \times C C}{(1+r)^{i}}
$$

- Feedstock cost

The adjustment of yearly feedstock consumption is calculated based on the plant capacity and the feedstock conversion efficiency of biodiesel production. The total feedstock cost is the multiplication of the total annual consumption of feedstock and the feedstock cost. Therefore, the sum of the feedstock cost for the project life span can be determined by the following equation [62]:

$$
F C=\sum_{i=1}^{n} \frac{F P \times F U}{(1+r)^{i}}
$$


- Salvage value

The value of the remains of plant assets or components at the end of the life span of the project is known as the salvage value. The depreciation rate is expected to occur annually for this project. The model of salvage value is based on the substitution cost instead of the initial cost. This salvage value can be calculated by the following equation [62]:

$$
S V=R C \times(1-d)^{n-1}
$$

Consequently, the salvage cost of the current value can be determined by the equation below:

$$
S V_{P V}=\sum_{i=1}^{n} \frac{R C \times(1-d)^{n-1}}{(1+r)^{n}}
$$

- By-product credits

The biodiesel production process produces the by-product named Glycerol, which is usually sold as a useful by-product. However, the glycerol can be converted for such purposes as fuel Oxygenates (additive), Reforming Syngas, Glycerol Carbonate, Propylene glycol etc. The glycerol actually can be utilized for solvent, antifreeze, pharmaceuticals and others by the conversion of the catalyst of glycerol that has been found [65].

The fixed price for glycerol calculated based on the biodiesel production capacity, and the value of credit of by-product for the plant life span and it is calculated by the following equation:

$$
B P=\sum_{i=1}^{n} \frac{G P \times G C F \times P C \times 1000}{(1+r)^{i}}
$$

- Payback Period

The payback period is the time required to get back the initial investment spent. The payback period is the ratio between the capital cost, annual total biodiesel sales, the annual total production cost and annual total tax. The payback period can be determined as follows [63]:

$$
P P=\frac{C C}{T B S-T P C-T A X}
$$

Whereby,

$$
\begin{gathered}
T B S=\frac{B F P \times P C}{\rho} \\
T P C=1.1 \times \frac{L C C}{n} \\
T A X=(T B S-T P C) \times T R
\end{gathered}
$$

- Total biodiesel cost

The total biodiesel costs are a function of life cycle cost and the profit margin. The profit margin is that this study assumed to be $10 \%$ of biodiesel production cost. Therefore, in this case, the total biodiesel production determined as follows [62]:

$$
T P C=1.1 \times \frac{L C C}{n}
$$


- Final biodiesel unit cost

The final biodiesel unit cost is calculated as a function of total biodiesel production cost usually per in cost per litre of biodiesel produced. In defining the conversion unit, the correlation between the density of biodiesel and the total biodiesel production cost over the production capability annually. Therefore, the final unit cost of biodiesel can be determined by the following equation [63]:

$$
F B C=\frac{T P C \times \rho}{P C}
$$

\subsubsection{Potential Fuel Saving}

There is a small difference between the calorific value of diesel and biodiesel fuels have some dissimilarity in heating value or calorific value. This difference will increase the fuel consumption of the vehicle. In this case, fuel substitution ratio between the diesel to biodiesel needs to be calculated. This ratio can be determined by the following equation:

$$
S R=\frac{H V G}{H V B}
$$

The total fuel substitution of diesel with biodiesel is a function of annual diesel consumption replacement based on substitution ratio, which can be presented by applying the equation below:

$$
G R_{i}=\eta \times G C_{i}
$$

The total required biodiesel substitution with the diesel fuel can be calculated using diesel fuel replacement times with biodiesel to the fossil diesel substitution ratio that is presented by the following equation:

$$
B C_{i}=G R_{i} \times S R
$$

The total potential fuel savings is a function of the replacement of diesel fuel and diesel fuel energy content that can be determined as follows:

$$
T F S=\sum_{i}^{n} G R_{i} \times E C
$$

\subsubsection{Sensitivity Analysis}

The sensitivity analysis is the analysis of the performance predicted that changes by changing key assumptions and predictions based on basic values. Uncertainty of prices in the international market also leads to the examination, so that it can change the project outcome. The most important variables in calculating the sensitivity analysis are the price of feedstock, operating costs, initial capital costs and discount rate. In a sensitivity analysis, the most important variable is the price of feedstock. It depends on the value of the market and is expected to be sensitive to biodiesel world prices. It can lead to two different results. The feedstock prices will tend to rise if biodiesel production capacity exceeds supply or production of the feedstocks, whereas feedstock prices will decline if the feedstock producers augment the production of feedstock above the figures of biodiesel capacity needs. If the quality of crude oil changes, the demand and supply of feedstocks also feed into the cost of production through the changes in biodiesel quality and yield.

\subsubsection{Biodiesel Taxation and Subsidy Scenarios}

The policy of subsidies scenario and taxation for the biodiesel fuel affected the final biodiesel price in the country. The analysis is usually a comparison of taxation and subsidy scenarios of fossil diesel and final biodiesel product prices are at different rates. The scenarios are calculated based on the total 
tax exemption. Meanwhile, a subsidy is necessary for biodiesel to be competitive with the price of fossil diesel. The cost of subsidy usually is chosen depending on the existing subsidy rate of diesel fuel and petrol fuel in certain countries.

\subsubsection{Potential Environmental Impact}

The impact on environment calculated in this study is the emission reduction potential by replacing fossil diesel with biodiesel, the crop land use and the carbon payback period of the ecosystem.

\subsection{Total Carbon Saving}

The total carbon saving potential is determined as a function of the potential net emission reduced and the amount of biodiesel required. The value can be determined as follows:

$$
T C S_{i}=N A E \times B C_{i}
$$

- Cropland needed

The cropland required is determined by dividing the feedstock needed with the biodiesel produced, which can be evaluated as follows:

$$
C L R=\frac{B C \times 1000}{E Y}
$$

- Ecosystem carbon payback period

The ecosystem carbon payback period is calculated by dividing the difference between the converting natural land carbons stock to become biodiesel feedstock cropland with the potential annual carbon savings of using fuel from biodiesel. This can be determined as follows:

$$
C P P=\frac{L S C-B C C}{T C S / C L R}
$$

\section{Results}

Based on its characteristics, Ceiba pentandra has the potential to be one of the biodiesel feedstocks in the future. This was proven by the experimental results that are tabulated in Table 1. In order to conduct the techno-economic analysis and sensitivity analysis, the properties of Ceiba pentandra have

\begin{tabular}{|c|c|c|c|c|c|c|c|}
\hline Properties & Unit & $\begin{array}{c}\text { ASTM D6751 } \\
\text { Limit }\end{array}$ & $\begin{array}{c}\text { EN 14,214 } \\
\text { Limit }\end{array}$ & CIME [66] & CPME [67] & RTME [62] & SFME [68] \\
\hline $\begin{array}{l}\text { Kinematic viscosity } \\
\text { at } 40^{\circ} \mathrm{C}\end{array}$ & $\mathrm{mm}^{2} / \mathrm{s}$ & $1.9-6.0$ & $3.5-5.0$ & 3.45 & 4.16 & 6.48 & 3.96 \\
\hline Density at $15^{\circ} \mathrm{C}$ & $\mathrm{kg} / \mathrm{m}^{3}$ & 880 & $860-900$ & 877.6 & 876.9 & 892 & 879.1 \\
\hline Flash point & ${ }^{\circ} \mathrm{C}$ & Min. 130 & Min. 120 & 165.5 & 156.5 & 206.5 & 160.5 \\
\hline Pour point & ${ }^{\circ} \mathrm{C}$ & -15 to 16 & - & 2.0 & 2.5 & -2 & -3.0 \\
\hline Cloud point & ${ }^{\circ} \mathrm{C}$ & -3 to 12 & - & 2.0 & 3.0 & -1 & -3.0 \\
\hline Calorific value & $\mathrm{MJ} / \mathrm{kg}$ & - & $35 \mathrm{~min}$ & 41.442 & 40.493 & 40.098 & 40.427 \\
\hline Acid value & $\mathrm{mg} \mathrm{KOH} / \mathrm{g}$ & $0.5 \max$ & 0.5 max. & 0.34 & 0.38 & 0.26 & 0.14 \\
\hline $\begin{array}{c}\text { Copper corrosion } \\
\text { strip }\end{array}$ & - & $3 \max$ & - & $1 \mathrm{a}$ & $1 \mathrm{a}$ & $1 b$ & - \\
\hline Water content & \%vol. & 0.05 max. & $500^{\mathrm{a}} \max$. & 0.015 & 0.045 & - & - \\
\hline $\begin{array}{l}\text { Sulfur content (S } 15 \\
\text { grade) }\end{array}$ & ppm & 15 max. & - & 6.23 & 13.97 & 14.85 & - \\
\hline FAME content & $\% \mathrm{~m} / \mathrm{m}$ & - & $96.5 \mathrm{~min}$ & 98.7 & 98.6 & - & - \\
\hline
\end{tabular}
been investigated experimentally.

Table 1. Physicochemical properties of Ceiba pentandra biodiesel and other sources of biodiesels.

a mg/kg, CIME: Calophyllum inophyllum Methyl ester, FAME: Fatty Acid Methyl ester, RTME: Reuteulis Trisperma Methyl ester, SFME: Sterculia feotida Methyl ester. 


\subsection{Economic Indicators}

For this task, the lifetime has been fixed for 20 years with the starting year of 2019. This consists of a year for the start-up of the plant and some constructions. For the project lifetime, the plant capacity has been estimated to operate at $100 \%$. The calculation of the capital costs is based on the land area needed, basic equipment and instrumentation needed and the construction of the building for the plant. In this analysis, crude Ceiba pentandra oil was utilized as a biodiesel production sources of feedstocks. Fifty ktons of Ceiba pentandra crude oil are necessary to make 49 ktons of biodiesel with a total $98 \%$ biodiesel conversion yield. From this value, the selling price can be estimated for the first 10 years as $0.58 \$ / \mathrm{L}$ and for the 11 th to the end it is $2.00 \$ / \mathrm{L}$. The outcome from the economic data and indicators has been shown in Table 2.

Table 2. Summary of the economic data and indicators.

\begin{tabular}{|c|c|}
\hline Input Data & Data \\
\hline Year enacted & 2019 \\
\hline Project lifetime (n. Year) & 20 \\
\hline Interest rate $(\mathrm{r}, \%)$ & $8.0 \%$ \\
\hline Plant capacity (ton/year) & 50,000 \\
\hline Feedstock cost, S (\%) & $2.0 \%$ \\
\hline Feedstock price (\$/ton) & 980 \\
\hline Operating cost/unit (Or, \$/ton/FAME) & 250 \\
\hline Maintenance cost/unit (Or, \$/ton/FAME) & $2.50 \%$ \\
\hline The yield of biodiesel (FAME) conversion & $98 \%$ \\
\hline $\begin{array}{l}\text { Feedstock price, Feedstock consumption (FP-FU, } \\
\text { Tons) }\end{array}$ & 51,020 \\
\hline Depreciation Model (D, \%) & $10 \%$ \\
\hline Replacement Cost (\$ Million) & $10,000,000$ \\
\hline $\begin{array}{l}\text { Glycerol Conversion Factor from Feedstock Oil (Gcf, } \\
\text { kg/Ton) }\end{array}$ & 100 \\
\hline By Product Price (\$/Ton Glycerol) & 300 \\
\hline Glycerol Price by Product (Tons) & 5102.04 \\
\hline By Product Price Increase Ratio (\%) & $0 \%$ \\
\hline $\operatorname{Tax}(\%)$ & $15 \%$ \\
\hline Subsidy for Biodiesel Cost $(\$ / L) G 1$ & 0.1 \\
\hline Subsidy for Biodiesel Cost (\$/L) G 2 & 0.18 \\
\hline Diesel (Fossil) Selling Price (\$/L) & 0.58 \\
\hline Biodiesel Selling Price for First to Tenth Year $(\$ / L)$ & 0.58 \\
\hline Biodiesel Selling Price for Eleven To Till The End $(\$ / \mathrm{L})$ & 2 \\
\hline Density $\left(\mathrm{kg} / \mathrm{m}^{3}\right)$ & 877 \\
\hline
\end{tabular}

\subsection{Life Cycle Cost Analysis and Payback Period}

By using a biodiesel plant with a capacity of 50 ktons located in Malaysia as tabulated in Table 2, the techno-economic analysis can be calculated. These results are shown in Figure 3 and Table 3. The Life cycle cost analysis of Ceiba pentandra biodiesel process production is around \$701 million. Life cycle cost analysis of Ceiba pentandra biodiesel process can be calculated by using Equation (1), which is

$$
L C C=C C+O C+M C+F C-S V-B P C
$$




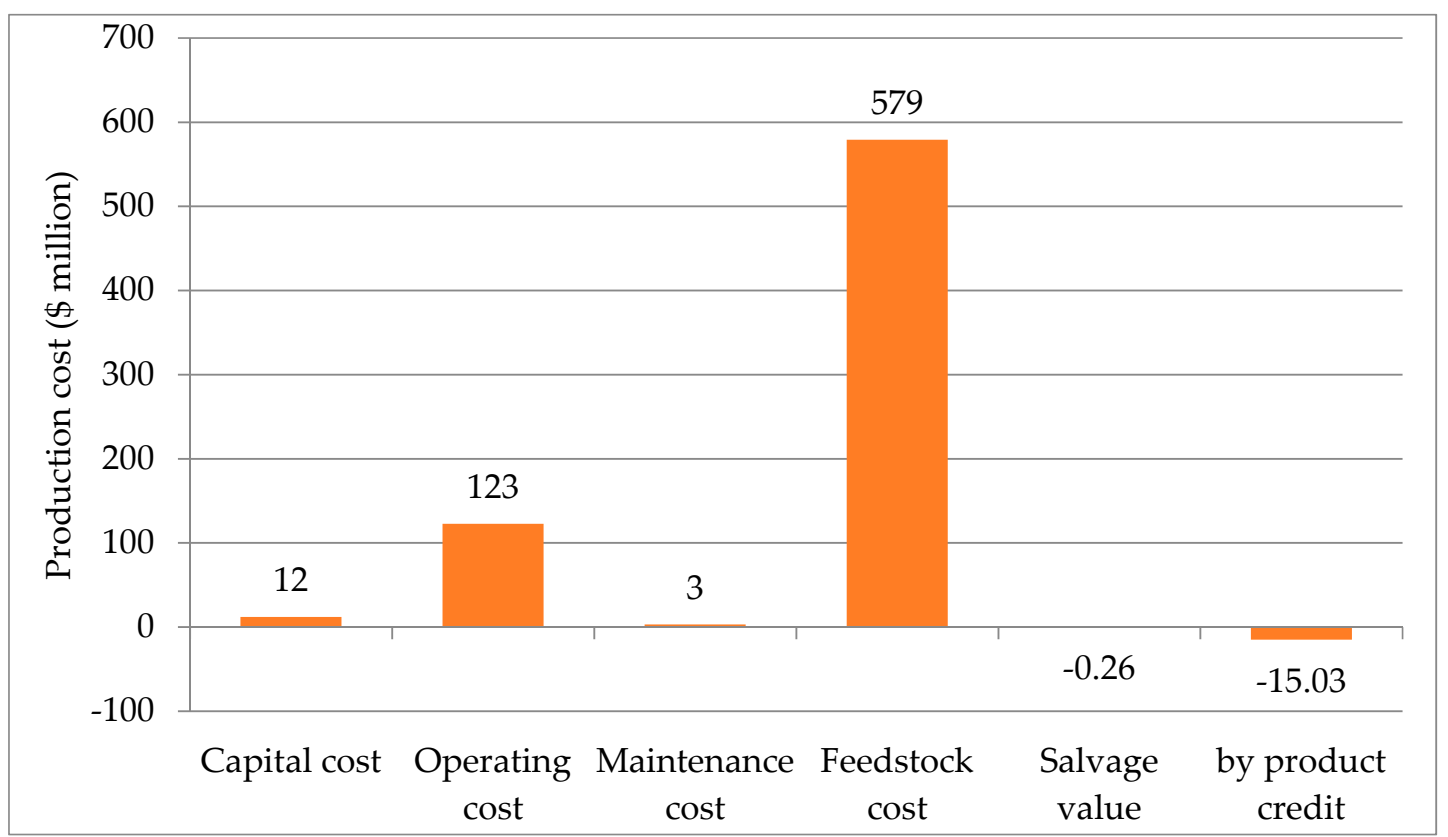

Figure 3. Distribution of Ceiba pentandra biodiesel production.

Table 3. Summary of total production cost and a payback period of the biodiesel production plant.

\begin{tabular}{ccc}
\hline Indicator & Life Cycle Cost (\$) & Unit Cost (\$/L of Biodiesel) \\
\hline Capital cost & $11,882,425$ & 0.0119 \\
Operating cost & $122,726,843$ & 0.1227 \\
Maintenance cost & $2,916,585$ & 0.0029 \\
Feedstock cost & $579,013,752$ & 0.5790 \\
Salvage value & 260,841 & 0.0003 \\
By product credit & $15,027,777$ & 0.0150 \\
Total biodiesel cost & $701,250,988$ & 0,6765 \\
Payback period (year) & & 3.7 \\
\hline
\end{tabular}

Based on Table 2, it shows the capital cost, feedstock cost, operating cost, salvage value, maintenance cost, and credit of by-product. From that, it can be concluded that in the final biodiesel production cost, the cost of feedstock has the highest portion. The unit cost of the feedstock cost is $\$ 0.58 / \mathrm{L}$. For the operating cost, the unit cost is $\$ 0.12 / \mathrm{L}$. The sale of by-products gives $\$ 15$ million and $\$ 0.015 / \mathrm{L}$ unit cost.

\subsection{Potential Fuel Saving}

The total diesel fuel substitution can be calculated based on an annual consumption of diesel fuel to the ratio of biodiesel substitution. The overall biodiesel required for substituting the diesel fuel is calculated by diesel fuel replacement, multiplied with diesel to biodiesel substitution ratio. In view of the fact that diesel and biodiesel fuels have some similarity in heating value. Therefore, some additional amount of biodiesel fuels is required to replace the higher heating value of diesel fuel. The fossil diesel consumption and potential diesel replacement are tabulated in Table 4. 
Table 4. Fossil diesel consumption and potential diesel replacement.

\begin{tabular}{ccccc}
\hline \multirow{2}{*}{ Year } & \multicolumn{2}{c}{ Diesel Consumption } & \multicolumn{2}{c}{ Diesel Replacement/Saving } \\
\cline { 2 - 5 } & (Million Litres) & (Tons) & (Million Litres) & (Tons) \\
\hline 2019 & 8778 & $8,526,812$ & 509 & 426,341 \\
2020 & 9020 & $8,761,778$ & 523 & 438,089 \\
2021 & 9261 & $8,996,743$ & 537 & 449,837 \\
2022 & 9503 & $9,231,709$ & 551 & 461,585 \\
2023 & 9745 & $9,466,675$ & 566 & 473,334 \\
2024 & 9987 & $9,701,641$ & 580 & 485,082 \\
2025 & 10,229 & $9,936,607$ & 594 & 496,830 \\
2026 & 10,471 & $10,171,573$ & 608 & 508,579 \\
2027 & 10,713 & $10,406,539$ & 622 & 520,327 \\
2028 & 10,955 & $10,641,505$ & 636 & 532,075 \\
2029 & 11,197 & $10,876,471$ & 650 & 543,824 \\
2030 & 11,438 & $11,111,437$ & 664 & 555,572 \\
2031 & 11,680 & $11,346,403$ & 678 & 567,320 \\
2032 & 11,922 & $11,581,369$ & 692 & 579,068 \\
2033 & 12,164 & $11,816,335$ & 706 & 590,817 \\
2034 & 12,406 & $12,051,301$ & 720 & 602,565 \\
2035 & 12,648 & $12,286,267$ & 734 & 614,313 \\
2036 & 12,890 & $12,521,233$ & 748 & 626,062 \\
2037 & 13,132 & $12,756,198$ & 762 & 637,810 \\
2038 & 13373 & $12,991,164$ & 776 & 649,558 \\
\hline
\end{tabular}

\subsection{Sensitivity Analysis}

The sensitivity analysis results can be figured out in Figure 4. This consists of five input variables such as initial capital cost, operating rate, conversion yield of oil, discount rate and the feedstock price. The difference in the price of the feedstock is corresponding to the main impact of the life cycle cost. For instance, the crude oil price of Ceiba pentandra is $\$ 680 /$ ton that decreases the life cycle production cost to $\$ 524$ million as presented in Figure 4. However, if the price of CCPO rises to $\$ 1280 /$ ton, the life cycle cost of biodiesel production will rise to $\$ 878$ million. As for the discount rate increase by $10 \%$ per year, it will affect a $13 \%$ decrease in the total life cycle cost of biodiesel production. The operating rate of $\$ 175 /$ ton only affected the total life cycle production cost to $\$ 664$ million as well as operating cost of $\$ 325 /$ ton will change the total life cycle cost of biodiesel production to $\$ 738$ million. Crude oil prices for biodiesel feedstocks have been observed over the past two years. The oil conversion and industrial operating costs are the last that affected on-going cost, but both costs can offset the fluctuation of feedstock prices. In addition, the production costs can still be reduced by improvements in the conversion process of biodiesel production.

Figure 5, shows the feedstock price fluctuation on biodiesel production cost for Ceiba pentandra. The differences in operating cost and oil conversion yield have the least impact on running cost. However, both can counteract important variation in the feedstock price. By continuously improving the conversion processes of biodiesel and higher operating efficiency, it can decrease the whole biodiesel production cost significantly. In addition, the effect of the price fluctuation of Ceiba pentandra crude oil was additionally investigated. 


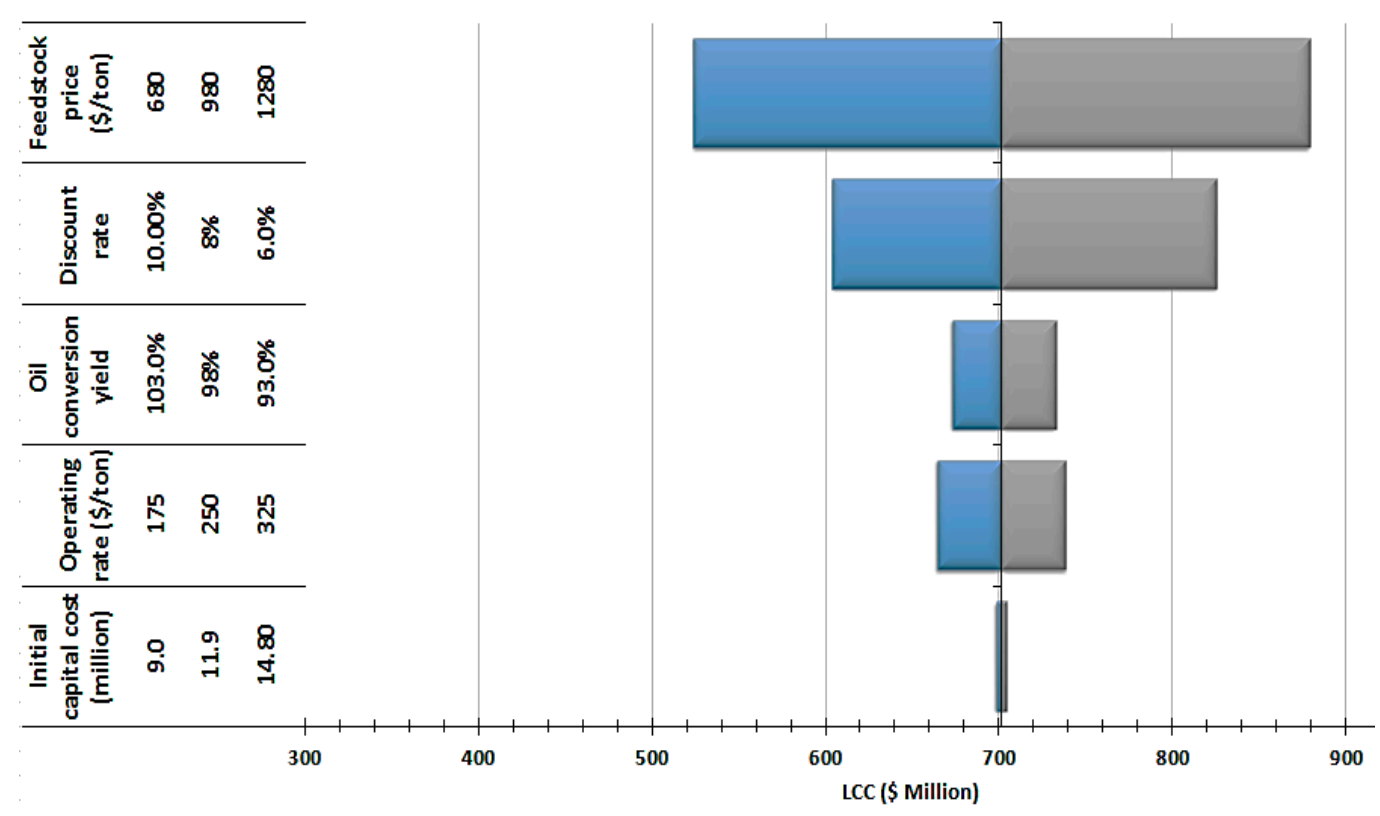

Figure 4. Sensitivity analysis of life cycle costs for Ceiba pentandra biodiesel production.

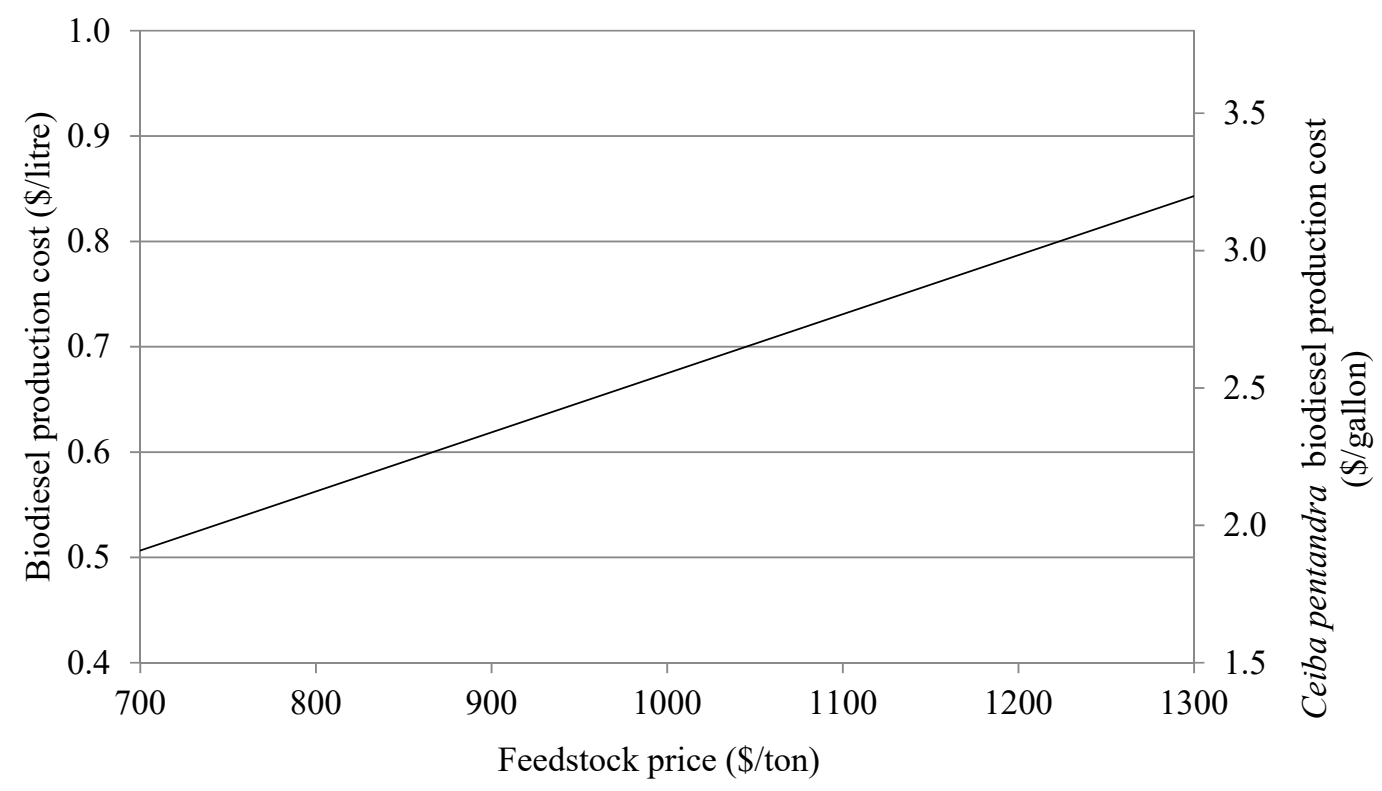

Figure 5. The impact of feedstock oil price on the biodiesel production cost.

\subsection{Biodiesel Taxation and Subsidy Scenarios}

Subsidy and taxation scenarios are necessary for the final cost of biodiesel and it is tabulated in Table 5. Based on Table 5, it explains the differences of final biodiesel price with petrol diesel at various scenarios of subsidy and taxation, such as total tax exemption $15 \%, \$ 0.10 / \mathrm{L}$ subsidy and lastly $\$ 0.18 /$ litre for biodiesel compared to the price of fossil diesel. The subsidy cost was fixed at $\$ 0.10 / \mathrm{L}$ and $\$ 0.18 / \mathrm{L}$. This was being set based on the latest cost of subsidies and diesel price in this country. From Table 5, with a subsidy, it is possible to match the total cost of biodiesel and fossil diesel price. 
Table 5. Biodiesel taxation and subsidy level scenarios at current production cost.

\begin{tabular}{|c|c|c|c|c|c|}
\hline \multirow[b]{2}{*}{$\$ / L$} & \multicolumn{4}{|c|}{ Biodiesel } & \multirow[b]{2}{*}{ Fossil Diesel } \\
\hline & $\begin{array}{c}\text { Total Tax } \\
\text { Exemption }\end{array}$ & $15 \%$ of Tax & $\begin{array}{c}\text { Subsidy }(\$ / L) \\
0.10\end{array}$ & $\begin{array}{c}\text { Subsidy }(\$ / L) \\
0.18\end{array}$ & \\
\hline Biodiesel cost & 0.676 & 0.676 & 0.676 & 0.676 & - \\
\hline Taxes/subsidy & 0 & 0.101 & 0.100 & 0.180 & - \\
\hline Total & 0.676 & 0.778 & 0.576 & 0.496 & 0.581 \\
\hline Total cost & 0.687 & 0.790 & 0.586 & 0.504 & 0.581 \\
\hline
\end{tabular}

The breakeven price of biodiesel from Ceiba pentandra of various crude petroleum oil price and crude Ceiba pentandra oil is presented in Figure 6. There are two parts of Figure 6; the first part is an area on the top of the line that represents the subsidy required for replacement of diesel fuel with Ceiba pentandra biodiesel fuel, while in the lower area of the line is the part of potential savings generated by substitution. For example, when the crude oil prices are $\$ 100 /$ barrel, the price of biodiesel fuels is equivalent to diesel at CCPO price $\$ 1585 /$ ton. Then, if the CCPO price increases above $\$ 1585 /$ ton, the subsidies are needed to keep the use of biodiesel still running. However, if the CCPO price decreased below $\$ 1585 /$ ton, it will result in cost savings by replacing diesel fuel with biodiesel fuel.

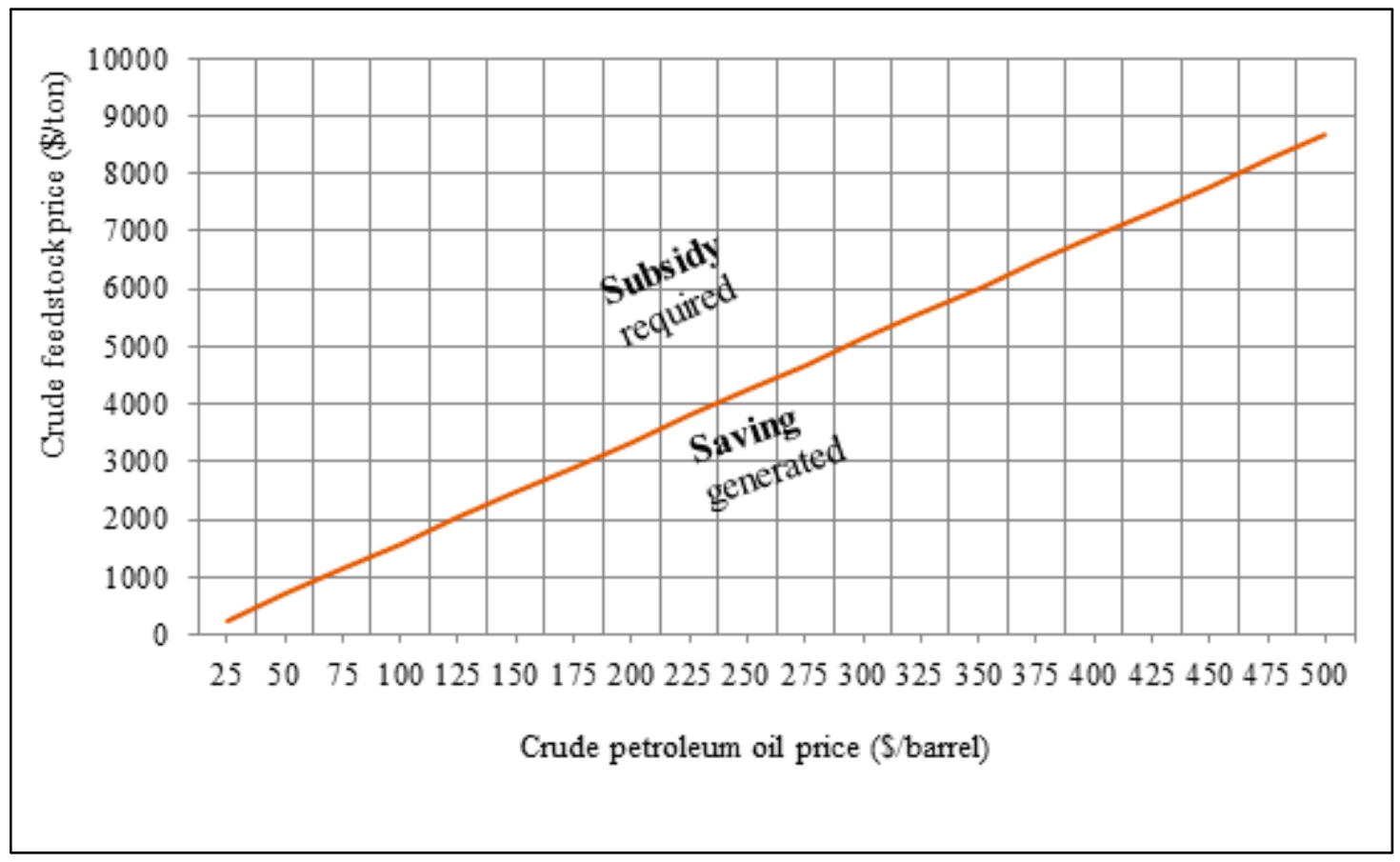

Figure 6. The breakeven price for biodiesel production at different petroleum and feedstock prices.

Figure 7 illustrates the taxation and subsidy scenarios of the biodiesel production cost of feedstock price of Ceiba pentandra. Based on the graph, the biodiesel price is very competitive with fossil diesel. This happened when the feedstock prices are below $\$ 1 / \mathrm{kg}$, the price of biodiesel can compete with fossil diesel with tax exemption. The subsidized required for biodiesel are from $\$ 0.10 / \mathrm{L}$ and $\$ 0.18 / \mathrm{L}$, the competitiveness of feedstock prices for biodiesel with fossil diesel can reach about $\$ 1 / \mathrm{kg}$ and $\$ 1.17 / \mathrm{kg}$, respectively. However, when the feedstock prices increase up to $\$ 1.17 / \mathrm{kg}$, the biodiesel price can be higher than fossil diesel even though biodiesel has been given a subsidy of $\$ 0.18 / \mathrm{L}$. These are necessary in order to make biodiesel competitive with fossil diesel. 


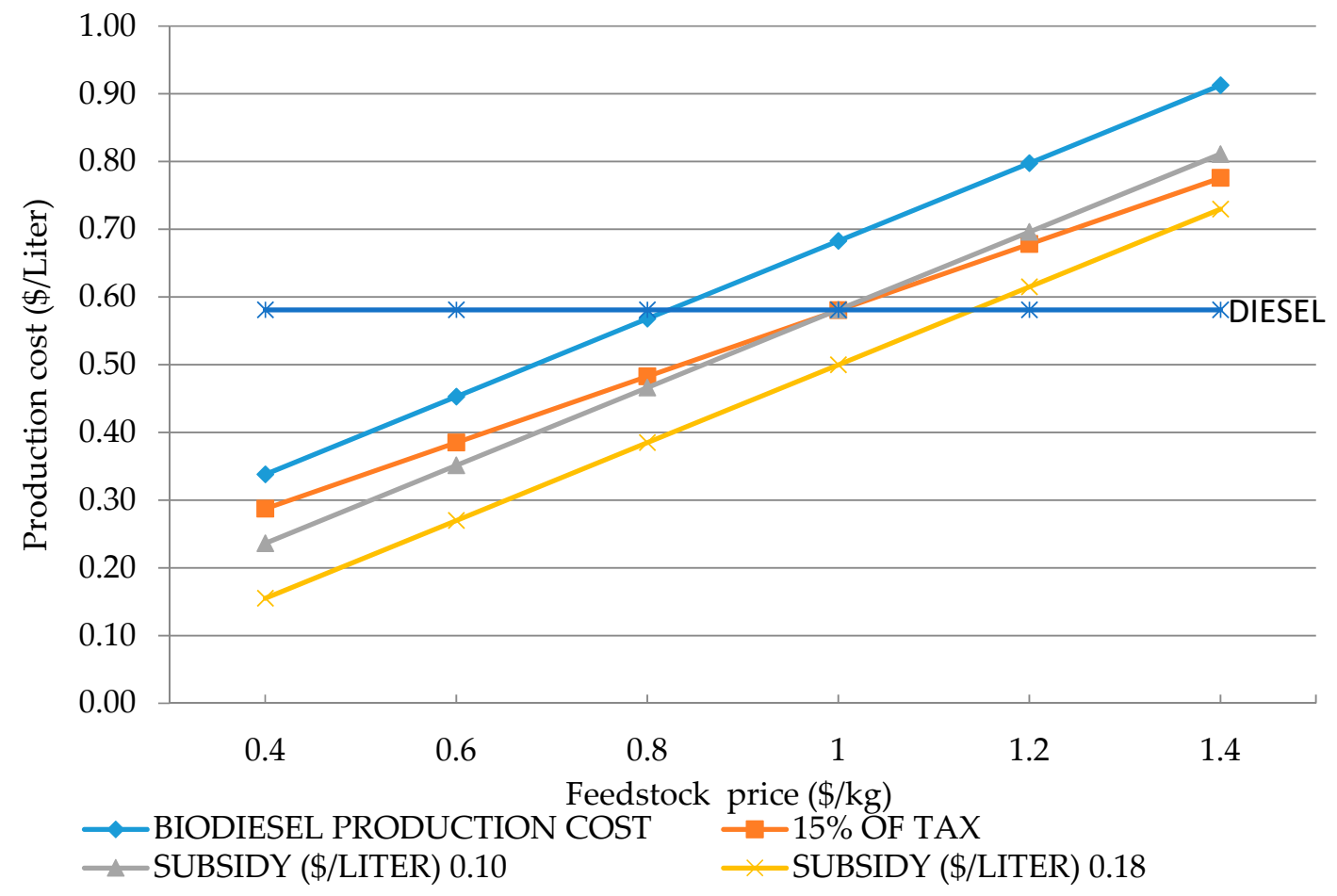

Figure 7. Taxation and subsidy scenarios of biodiesel production cost on feedstock price.

\subsection{Potential Environmental Impact}

The outcomes of the environmental impacts presented are probable emission reductions, and cropland has been used for the feedstock of biodiesel and an environment carbon payback period. To calculate the carbon saving potential, the net avoided emission should be multiplied by the amount of biodiesel required. The needed cropland is based on the need for feedstock for biodiesel production. Meanwhile, to estimate the ecosystem carbon payback period, dividing the difference of the carbons stock and the natural land changing to cropland for biodiesel production. The outcomes tabulated in Table 6 presents the cropland for biodiesel feedstock with the annual carbon savings by utilizing fuel from biodiesel. An increase in the use of biodiesel to replace fossil diesel causes an increase in the amount of biodiesel needed to simplify the substitution of biodiesel to fossil diesel. Along with the increased biodiesel demand, the need for feedstocks to supply biodiesel fuel requires more agricultural land to supply biodiesel feedstock. Diesel substitution rates of $1 \%, 25 \%$ and $50 \%$ require land of $28 \mathrm{kHa}, 707 \mathrm{kHa}$ and $1414 \mathrm{kHa}$, respectively. From Figure 8, it shows the differentiation of overall carbon emissions by biodiesel and fossil diesel fuel. From Figure 8, it can be seen that even with the replacement of diesel, total carbon emission will still increase, but this increase is less than the increase accounted for diesel. It is because the carbon emission factor in fossil diesel is higher than biodiesel. The differences in carbon emissions between fossil diesel provide benefits to biodiesel so as to save total carbon by diesel substitution and make biodiesel more efficient with lower pollution levels. The fossil diesel substitution rate of 1\% results in total energy savings from diesel of 3,675,056 MJ and total carbon saving of $129,356 \mathrm{~kg}$, and at the diesel replacement rate of $50 \%$, total energy savings from diesel and total carbon saving are 183,752,790 MJ and 6,467,798 kg, respectively Table 6. 
Table 6. The results, by changing the number of replacements for cropland required, total energy saving and total carbon saving.

\begin{tabular}{ccccccc}
\hline $\begin{array}{c}\text { Diesel } \\
\text { Consumption }\end{array}$ & $\begin{array}{c}\text { Diesel } \\
\text { Replacement } \\
\text { Rate }\end{array}$ & $\begin{array}{c}\text { Diesel } \\
\text { Replacement } \\
\text { Rate }\end{array}$ & $\begin{array}{c}\text { Biodiesel } \\
\text { Needed }\end{array}$ & $\begin{array}{c}\text { Cropland } \\
\text { Required }\end{array}$ & $\begin{array}{c}\text { Total Energy } \\
\text { Saving } \\
\text { (Diesel) }\end{array}$ & $\begin{array}{c}\text { Total } \\
\text { Carbon } \\
\text { Saving }\end{array}$ \\
\hline DC & & DR & BC & CLR & TES & TCS \\
\hline $8,526,812$ & $(\%)$ & $($ TONS) & (TONS) & $(\mathrm{HA})$ & $(\mathrm{GJ})$ & $($ KG) \\
(TONS) & & & & & & \\
\hline 2019 & $1 \%$ & 85,268 & 90,765 & 28,297 & $3,675,056$ & 129,356 \\
2020 & $2 \%$ & 170,536 & 181,529 & 56,594 & $7,350,112$ & 258,712 \\
2021 & $3 \%$ & 255,804 & 272,294 & 84,892 & $11,025,167$ & 388,068 \\
2022 & $4 \%$ & 341,072 & 363,058 & 113,189 & $14,700,223$ & 517,424 \\
2023 & $5 \%$ & 426,341 & 453,823 & 141,486 & $18,375,279$ & 646,780 \\
2024 & $6 \%$ & 511,609 & 544,587 & 169,783 & $22,050,335$ & 776,136 \\
2025 & $7 \%$ & 596,877 & 635,352 & 198,081 & $25,725,391$ & 905,492 \\
2026 & $8 \%$ & 682,145 & 726,116 & 226,378 & $29,400,446$ & $1,034,848$ \\
2027 & $9 \%$ & 767,413 & 816,881 & 254,675 & $33,075,502$ & $1,164,204$ \\
2028 & $10 \%$ & 852,681 & 907,645 & 282,972 & $36,750,558$ & $1,293,560$ \\
2029 & $15 \%$ & $1,279,022$ & $1,361,468$ & 424,459 & $55,125,837$ & $1,940,339$ \\
2030 & $20 \%$ & $1,705,362$ & $1,815,291$ & 565,945 & $73,501,116$ & $2,587,119$ \\
2031 & $25 \%$ & $2,131,703$ & $2,269,113$ & 707,431 & $91,876,395$ & $3,233,899$ \\
2032 & $30 \%$ & $2,558,043$ & $2,722,936$ & 848,917 & $110,251,674$ & $3,880,679$ \\
2033 & $35 \%$ & $2,984,384$ & $3,176,759$ & 990,403 & $128,626,953$ & $4,527,458$ \\
2034 & $40 \%$ & $3,410,725$ & $3,630,581$ & $1,131,890$ & $147,002,232$ & $5,174,238$ \\
2035 & $45 \%$ & $3,837,065$ & $4,084,404$ & $1,273,376$ & $165,377,511$ & $5,821,018$ \\
2036 & $50 \%$ & $4,263,406$ & $4,538,226$ & $1,414,862$ & $183,752,790$ & $6,467,798$ \\
\hline
\end{tabular}

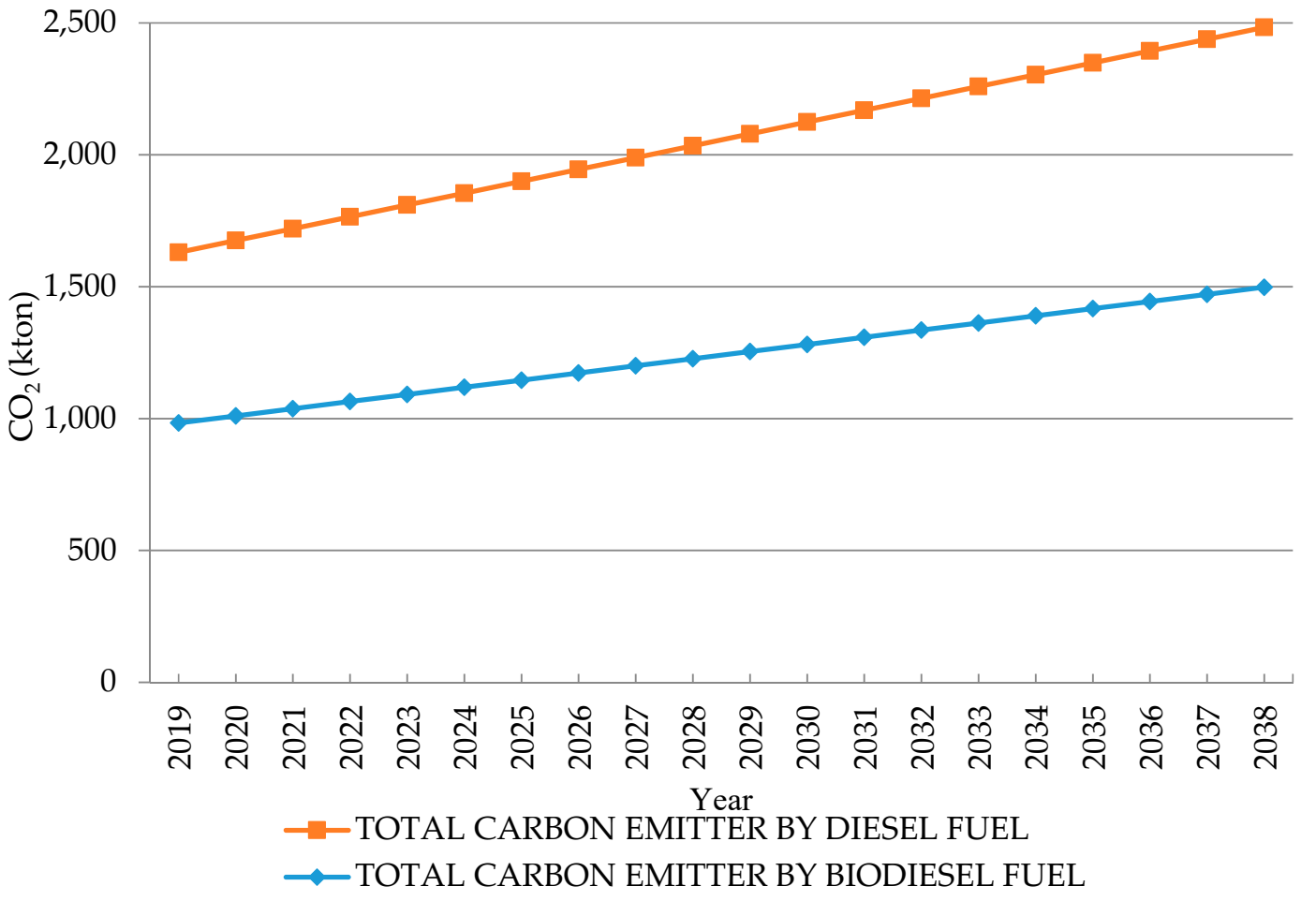

Figure 8. Total carbon emitter by diesel fuel and biodiesel fuel.

\section{Conclusions}

In this paper, the life cycle cost and sensitivity analysis of Ceiba pentandra as non-edible sources of feedstock for future production of biodiesel in Malaysia were conducted. The analyses were based on a biodiesel production plant of 50 ktons with an estimated 20-year plant lifespan. The main variables 
of life cycle cost analysis such as feedstock cost, operating cost, capital cost, maintenance cost, salvage value and credit of by-product were determined. Ceiba pentandra biodiesel physicochemical properties are within the standard limits. The cost of feedstock has the highest portion of the total biodiesel production cost. The calculation shows that, from the year 2019 to 2038, the most of cost was spent for feedstock, which is $\$ 579$ million, following by operating cost, capital cost and maintenance cost which are around $\$ 123$ million, 12 million and 3 million, respectively. From the calculation, the life cycle cost of the Ceiba pentandra is about $\$ 701$ million over the lifespan of the project. The sensitivity analysis shows that if the price of CCPO increases to $\$ 1280 /$ ton, the life cycle cost of biodiesel production will be increased to $\$ 878$ million, and whereas for the discount rate increase by $10 \%$ per year will produce $13 \%$ decrease in the total life cycle cost of biodiesel production. To be conclude, biodiesel production price only well-matched with diesel fuel if the tax and subsidy are applied. The further study of the biodiesel production should be applied more and more practically. This can help to increase the usage of biodiesel in Malaysia.

Author Contributions: N.A.M.J. and T.M.I.M., conceptualization and prepared the first draft of the paper and H.C.O. and A.S.S. editing the manuscript. A.H.S. and T.M.I.M. contributed to the supervision the study. T.M.I.R. contributed to developing the techno economy analysis, M.M. and S.M.A.R. revised the paper.

Funding: This research was supported by the financial support of AAIBE Chair of Renewable Energy (Grant no: 201801 KETTHA). It also received Direktorat Jenderal Penguatan Riset dan Pengembangan Kementerian Riset, Teknologi dan Pendidikan Tinggi Republik Indonesia, (Grant no. 147/SP2H/LT/DRPM/2019) and Politeknik Negeri Medan, Medan, Indonesia. The authors would like to acknowledge the support from Centre for Advanced Modeling and Geospatial Information System (CAMGIS), University of Technology Sydney, Australia under Grants 321740.2232397.

Acknowledgments: This research is funded by the Centre for Advanced Modeling and Geospatial Information Systems (CAMGIS), UTS under Grants 321740.2232397. The authors wish to acknowledge the financial support provided by the Direktorat Jenderal Penguatan Riset dan Pengembangan Kementerian Riset, Teknologi dan Pendidikan Tinggi Republik Indonesia (Grant no. 147/SP2H/LT/DRPM/2019) and Politeknik Negeri Medan, Medan, Indonesia. The authors also would like to acknowledge this research as supported the AAIBE Chair of Renewable grant no: 201,801 KETTHA, Malaysia for supporting this research.

Conflicts of Interest: The authors declare no conflict of interest.

\section{Nomenclatures}

$\begin{array}{ll}B C & \text { Biodiesel needed (tons) } \\ B C C & \text { Carbon stock for biodiesel cropland (ton/ha) } \\ B F P & \text { Biodiesel fuel price }(\$ / \mathrm{L}) \\ B P & \text { By-product credits }(\$) \\ C C & \text { Capital cost }(\$) \\ C L R & \text { Cropland required (ha) } \\ C P P & \text { Carbon payback period (year) } \\ C P W & \text { Compound present worth factor }(\$) \\ C C P O & \text { Crude Ceiba pentandra oil } \\ d & \text { Depreciation cost } \\ E C & \text { Energy content of diesel fuel }(\mathrm{GJ} / \text { ton) } \\ E Y & \text { Ethanol yield }(\mathrm{kg} / \text { ha) } \\ F B C & \text { Final biodiesel unit cost (\$/L) } \\ F C & \text { Feedstock cost }(\$) \\ F P & \text { Feedstock price }(\$) \\ F U & \text { Feedstock consumption }(\text { tons) }\end{array}$




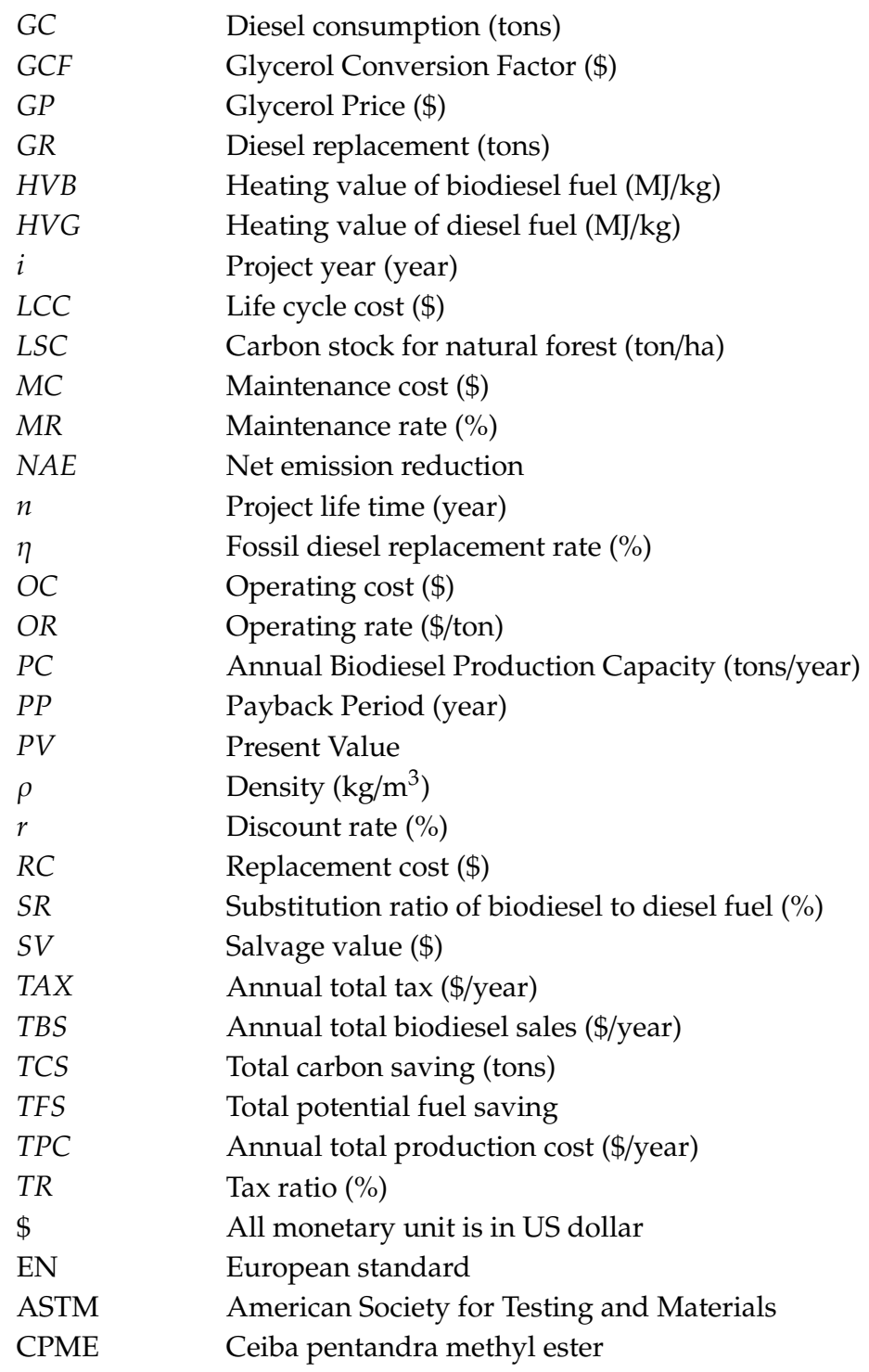

\section{References}

1. Mofijur, M.; Masjuki, H.H.; Kalam, M.A.; Atabani, A.E. Evaluation of biodiesel blending, engine performance and emissions characteristics of Jatropha curcas methyl ester: Malaysian perspective. Energy 2013, 55, 879-887. [CrossRef]

2. Mofijur, M.; Masjuki, H.H.; Kalam, M.A.; Atabani, A.E.; Fattah, I.M.R.; Mobarak, H.M. Comparative evaluation of performance and emission characteristics of Moringa oleifera and Palm oil based biodiesel in a diesel engine. Ind. Crop. Prod. 2014, 53, 78-84. [CrossRef]

3. Damanik, N.; Ong, H.C.; Mofijur, M.; Tong, C.W.; Silitonga, A.S.; Shamsuddin, A.H.; Sebayang, A.H.; Mahlia, T.M.I.; Wang, C.T.; Jang, J.H. The Performance and Exhaust Emissions of a Diesel Engine Fuelled with Calophyllum inophyllum-Palm Biodiesel. Processes 2019, 7, 597. [CrossRef]

4. Anwar, M.; Rasul, M.G.; Ashwath, N.; Rahman, M.M. Optimisation of second-generation biodiesel production from Australian native stone fruit oil using response surface method. Energies 2018, 11, 2566. [CrossRef]

5. Mofijur, M.; Rasul, M.G.; Hyde, J.; Azad, A.K.; Mamat, R.; Bhuiya, M.K. Role of biofuel and their binary (diesel-biodiesel) and ternary (ethanol-biodiesel-diesel) blends on internal combustion engines emission reduction. Renew. Sustain. Energy Rev. 2016, 53, 265-278. [CrossRef]

6. Kusumo, F.; Silitonga, A.S.; Masjuki, H.H.; Ong, H.C.; Siswantoro, J.; Mahlia, T.M.I. Optimization of transesterification process for Ceiba pentandra oil: A comparative study between kernel-based extreme learning machine and artificial neural networks. Energy 2017, 134, 24-34. [CrossRef] 
7. Norhasyima, R.S.; Mahlia, T.M.I. Advances in $\mathrm{CO}_{2}$ utilization technology: A patent landscape review. J. $\mathrm{CO}_{2}$ Util. 2018, 26, 323-335. [CrossRef]

8. Mehrali, M.; Latibari, S.T.; Mehrali, M.; Mahlia, T.M.I.; Metselaar, H.S.C.; Naghavi, M.S.; Sadeghinezhad, E.; Akhiani, A.R. Preparation and characterization of palmitic acid/graphene nanoplatelets composite with remarkable thermal conductivity as a novel shape-stabilized phase change material. Appl. Therm. Eng. 2013, 61, 633-640. [CrossRef]

9. Latibari, S.T.; Mehrali, M.; Mehrali, M.; Mahlia, T.M.I.; Metselaar, H.S.C. Synthesis, characterization and thermal properties of nanoencapsulated phase change materials via sol-gel method. Energy 2013, 61, 664-672. [CrossRef]

10. Emily Chow, T.H. Reuters: Malaysia in Talks to Move Start Up of B10 Biodiesel Program to July. Reuters web site. 2016. Available online: https://it.reuters.com/article/GCA-Commodities/idUSKCNOZ60IB (accessed on 2 June 2019).

11. Sani, Y.M.; Daud WM, A.W.; Abdul Raman, A.A. Biodiesel Feedstock and Production Technologies: Successes, Challenges and Prospects; IntechOpen: London, UK, 2012.

12. Dharma, S.; Masjuki, H.H.; Ong, H.C.; Sebayang, A.H.; Silitonga, A.S.; Kusumo, F.; Mahlia, T.M.I. Optimization of biodiesel production process for mixed Jatropha curcas-Ceiba pentandra biodiesel using response surface methodology. Energy Convers. Manag. 2016, 115, 178-190. [CrossRef]

13. Hudiyono, S.; Handayani, S.; Susilo, B. Esterification of glucose fatty acids of coconut oil catalyzed by Candida rugosa lipase EC 3.1.1.3 immobilized on an Indonesia's natural zeolite matrix. World Appl. Sci. J. 2012, 19, 1105-1111.

14. Silitonga, A.S.; Masjuki, H.H.; Mahlia, T.M.I.; Ong, H.C.; Chong, W.T. Experimental study on performance and exhaust emissions of a diesel engine fuelled with Ceiba pentandra biodiesel blends. Energy Convers. Manag. 2013, 76, 828-836. [CrossRef]

15. Silitonga, A.S.; Masjuki, H.H.; Ong, H.C.; Sebayang, A.H.; Dharma, S.; Kusumo, F.; Siswantoro, J.; Milano, J.; Daud, K.; Mahlia, T.M.I.; et al. Evaluation of the engine performance and exhaust emissions of biodiesel-bioethanol-diesel blends using kernel-based extreme learning machine. Energy 2018, 159, 1075-1087. [CrossRef]

16. Bhuiya MM, K.; Rasul, M.G.; Khan MM, K.; Ashwath, N.; Azad, A.K.; Hazrat, M.A. Second generation biodiesel: Potential alternative to edible oil-derived biodiesel. Energy Procedia 2014, 61, 1969-1972. [CrossRef]

17. Silitonga, A.; Shamsuddin, A.; Mahlia, T.; Milano, J.; Kusumo, F.; Siswantoro, J.; Dharma, S.; Sebayang, A.; Masjuki, H.; Ong, H.C. Biodiesel synthesis from Ceiba pentandra oil by microwave irradiation-assisted transesterification: ELM modeling and optimization. Renew. Energy 2019, 146, 1278-1291. [CrossRef]

18. Coh, B.H.H.; Ong, H.C.; Cheah, M.Y.; Chen, W.H.; Yu, K.L.; Mahlia, T.M.I. Sustainability of direct biodiesel synthesis from microalgae biomass: A critical review. Renew. Sustain. Energy Rev. 2019, 107, 59-74.

19. Hossain, N.; Zaini, J.; Mahlia, T.; Azad, A.K. Elemental, morphological and thermal analysis of mixed microalgae species from drain water. Renew. Energy 2019, 131, 617-624. [CrossRef]

20. Silitonga, A.S.; Masjuki, H.H.; Mahlia, T.M.I.; Ong, H.C.; Kusumo, F.; Aditiya, H.B.; Ghazali, N.N.N. Schleichera oleosa L oil as feedstock for biodiesel production. Fuel 2015, 156, 63-70. [CrossRef]

21. Ong, H.C.; Silitonga, A.S.; Mahlia, T.M.I.; Masjuki, H.H.; Chong, W.T. Investigation of biodiesel production from Cerbera manghas biofuel sources. Energy Procedia 2014, 61, 436-439. [CrossRef]

22. Silitonga, A.S.; Mahlia, T.M.I.; Kusumo, F.; Dharma, S.; Sebayang, A.H.; Sembiring, R.W.; Shamsuddin, A.H. Intensification of Reutealis trisperma biodiesel production using infrared radiation: Simulation, optimisation and validation. Renew. Energy 2019, 133, 520-527. [CrossRef]

23. Kusumo, F.; Silitonga, A.S.; Ong, H.C.; Masjuki, H.H.; Mahlia, T.M.I. A comparative study of ultrasound and infrared transesterification of Sterculia foetida oil for biodiesel production. Energy Sources Part A Recovery Util. Environ. Eff. 2017, 39, 1339-1346. [CrossRef]

24. Ong, H.C.; Milano, J.; Silitonga, A.S.; Hassan, M.H.; Shamsuddin, A.H.; Wang, C.T.; Indra Mahlia, T.M.; Siswantoro, J.; Kusumo, F.; Sutrisno, J. Biodiesel production from Calophyllum inophyllum-Ceiba pentandra oil mixture: Optimization and characterization. J. Clean. Prod. 2019, 219, 183-198. [CrossRef]

25. Leung, D.Y.C. Development of a clean biodiesel fuel in Hong Kong using recycled oil. Water Air Soil Pollut. 2001, 130, 277-282. [CrossRef]

26. Mushrush, G.W.; Wynne, J.H.; Willauer, H.D.; Lloyd, C.T.; Hughes, J.M.; Beal, E.J. Recycled soybean cooking oils as blending stocks for diesel fuels. Ind. Eng. Chem. Res. 2004, 43, 4944-4946. [CrossRef] 
27. Kumar, M.S.; Jaikumar, M. A comprehensive study on performance, emission and combustion behavior of a compression ignition engine fuelled with WCO (waste cooking oil) emulsion as fuel. J. Energy Inst. 2014, 87, 263-271. [CrossRef]

28. López, I.; Pinzi, S.; Leiva-Candia, D.; Dorado, M.P. Multiple response optimization to reduce exhaust emissions and fuel consumption of a diesel engine fueled with olive pomace oil methyl ester/diesel fuel blends. Energy 2016, 117, 398-404. [CrossRef]

29. de Almeida, V.F.; García-Moreno, P.J.; Guadix, A.; Guadix, E.M. Biodiesel production from mixtures of waste fish oil, palm oil and waste frying oil: Optimization of fuel properties. Fuel Process. Technol. 2015, 133, 152-160. [CrossRef]

30. Sanli, H.; Canakci, M.; Alptekin, E.; Turkcan, A.; Ozsezen, A.N. Effects of waste frying oil based methyl and ethyl ester biodiesel fuels on the performance, combustion and emission characteristics of a DI diesel engine. Fuel 2015, 159, 179-187. [CrossRef]

31. Zaher, F.A.; Megahed, O.A.; El Kinawy, O.S. Utilization of used frying oil as diesel engine fuel. Energy Sources 2003, 25, 819-826. [CrossRef]

32. Milano, J.; Ong, H.C.; Masjuki, H.H.; Silitonga, A.S.; Chen, W.H.; Kusumo, F.; Dharma, S.; Sebayang, A.H. Optimization of biodiesel production by microwave irradiation-assisted transesterification for waste cooking oil-Calophyllum inophyllum oil via response surface methodology. Energy Convers. Manag. 2018, 158, 400-415. [CrossRef]

33. Silitonga, A.S.; Mahlia, T.M.I.; Ong, H.C.; Riayatsyah, T.M.I.; Kusumo, F.; Ibrahim, H.; Dharma, S.; Gumilang, D. A comparative study of biodiesel production methods for Reutealis trisperma biodiesel. Energy Sources Part A Recovery Util. Environ. Eff. 2017, 39, 2006-2014. [CrossRef]

34. Ashok, B.; Thundil Karuppa Raj, R.; Nanthagopal, K.; Tapaswi, A.; Jindal, A.; Hari Subbish Kumar, S. Animal fat methyl ester as a fuel substitute for DI compression ignition engine. Int. J. Thermodyn. 2016, 19, $206-212$.

35. Ramos, Á.; García-Contreras, R.; Armas, O. Performance, combustion timing and emissions from a light duty vehicle at different altitudes fueled with animal fat biodiesel, GTL and diesel fuels. Appl. Energy 2016, 182, 507-517. [CrossRef]

36. Teixeira, L.S.G.; Couto, M.B.; Souza, G.S.; Filho, M.A.; Assis, J.C.R.; Guimarães, P.R.B.; Pontes, L.A.M.; Almeida, S.Q.; Teixeira, J.S.R. Characterization of beef tallow biodiesel and their mixtures with soybean biodiesel and mineral diesel fuel. Biomass Bioenergy 2010, 34, 438-441. [CrossRef]

37. Dhanasekaran, R.; Krishnamoorthy, V.; Rana, D.; Saravanan, S.; Nagendran, A.; Rajesh Kumar, B. A sustainable and eco-friendly fueling approach for direct-injection diesel engines using restaurant yellow grease and n-pentanol in blends with diesel fuel. Fuel 2017, 193, 419-431. [CrossRef]

38. Hanafi, S.A.; Elmelawy, M.S.; Shalaby, N.H.; El-Syed, H.A.; Eshaq, G.; Mostafa, M.S. Hydrocracking of waste chicken fat as a cost effective feedstock for renewable fuel production: A kinetic study. Egypt. J. Pet. 2016, 25, 531-537. [CrossRef]

39. Yahyaee, R.; Ghobadian, B.; Najafi, G. Waste fish oil biodiesel as a source of renewable fuel in Iran. Renew. Sustain. Energy Rev. 2013, 17, 312-319. [CrossRef]

40. Damanik, N.; Ong, H.C.; Tong, C.W.; Mahlia, T.M.I.; Silitonga, A.S. A review on the engine performance and exhaust emission characteristics of diesel engines fueled with biodiesel blends. Environ. Sci. Pollut. Res. 2018, 25, 15307-15325. [CrossRef]

41. Uddin, M.N.; Techato, K.; Taweekun, J.; Rahman, M.M.; Rasul, M.G.; Mahlia, T.M.I.; Ashrafur, S.M. An overview of recent developments in biomass pyrolysis technologies. Energies 2018, 11, 3115. [CrossRef]

42. Hena, S.; Fatimah, S.; Tabassum, S. Cultivation of algae consortium in a dairy farm wastewater for biodiesel production. Water Resour. Ind. 2015, 10, 1-14. [CrossRef]

43. Mahlia, T.; Syaheed, H.; Abas, A.; Kusumo, F.; Shamsuddin, A.; Ong, H.C.; Bilad, M. Organic Rankine Cycle (ORC) System Applications for Solar Energy: Recent Technological Advances. Energies 2019, 12, 2930. [CrossRef]

44. Davis, R.; Aden, A.; Pienkos, P.T. Techno-economic analysis of autotrophic microalgae for fuel production. Appl. Energy 2011, 88, 3524-3531. [CrossRef]

45. Mofijur, M.; Mahlia, T.M.I.; Silitonga, A.S.; Ong, H.C.; Silakhori, M.; Hasan, M.H.; Putra, N.; Rahman, S. Phase Change Materials (PCM) for Solar Energy Usages and Storage: An Overview. Energies 2019, 12, 3167. [CrossRef] 
46. Makareviciene, V.; Gumbyte, M.; Skorupskaite, V.; Sendzikiene, E. Biodiesel fuel production by enzymatic microalgae oil transesterification with ethanol. J. Renew. Sustain. Energy 2017, 9, 023101. [CrossRef]

47. Silitonga, A.S.; Masjuki, H.H.; Ong, H.C.; Mahlia, T.M.I.; Kusumo, F. Optimization of extraction of lipid from Isochrysis galbana microalgae species for biodiesel synthesis. Energy Sources Part A Recovery Util. Environ. Eff. 2017, 39, 1167-1175. [CrossRef]

48. Aditiya, H.B.; Chong, W.T.; Mahlia, T.M.I.; Sebayang, A.H.; Berawi, M.A.; Nur, H. Second generation bioethanol potential from selected Malaysia's biodiversity biomasses: A review. Waste Manag. 2016, 47, 46-61. [CrossRef] [PubMed]

49. Alhamid, M.I.; Daud, Y.; Surachman, A.; Sugiyono, A.; Aditya, H.B.; Mahlia TM, I. Potential of geothermal energy for electricity generation in Indonesia: A review. Renew. Sustain. Energy Rev. 2016, 53, 733-740.

50. Amin, M.; Putra, N.; Kosasih, E.A.; Prawiro, E.; Luanto, R.A.; Mahlia, T.M.I. Thermal properties of beeswax/graphene phase change material as energy storage for building applications. Appl. Therm. Eng. 2017, 112, 273-280. [CrossRef]

51. Ismail, M.S.; Moghavvemi, M.; Mahlia, T.M.I. Techno-economic analysis of an optimized photovoltaic and diesel generator hybrid power system for remote houses in a tropical climate. Energy Convers. Manag. 2013, 69, 163-173. [CrossRef]

52. Ismail, M.S.; Moghavvemi, M.; Mahlia, T.M.I. Characterization of PV panel and global optimization of its model parameters using genetic algorithm. Energy Convers. Manag. 2013, 73, 10-25. [CrossRef]

53. Ong, H.C.; Masjuki, H.H.; Mahlia, T.M.I.; Silitonga, A.S.; Chong, W.T.; Yusaf, T. Engine performance and emissions using Jatropha curcas, Ceiba pentandra and Calophyllum inophyllum biodiesel in a CI diesel engine. Energy 2014, 69, 427-445. [CrossRef]

54. Pratt, L.M.; Strothers, J.; Pinnock, T.; Hilaire, D.S.; Bacolod, B.; Cai, Z.B.; Sim, Y.L. Hydrocarbon fuels from brown grease: Moving from the research laboratory toward an industrial process. In AIP Conference Proceedings; AIP Publishing: Melville, NY, USA, 2017.

55. Arslan, R.; Ulusoy, Y. Utilization of waste cooking oil as an alternative fuel for Turkey. In Proceedings of the 2016 IEEE International Conference on Renewable Energy Research and Applications (ICRERA), Birmingham, UK, 20-23 November 2016; pp. 1-6.

56. Patel, R.; Duran, S.K. Performance characteristics of waste cooking oil produced biodiesel/diesel fuel blends. Int. J. Mech. Eng. Technol. 2017, 8, 1485-1491.

57. Yang, J.; Fujiwara, T.; Geng, Q. Life cycle assessment of biodiesel fuel production from waste cooking oil in Okayama City. J. Mater. Cycles Waste Manag. 2017, 19, 1457-1467. [CrossRef]

58. Chen, C.Y.; Lee, W.J.; Mwangi, J.K.; Wang, L.C.; Wu, J.L.; Lin, S.L. Reduction of persistent organic pollutant emissions during incinerator start-up by using crude waste cooking oil as an alternative fuel. Aerosol Air Qual. Res. 2017, 17, 899-912. [CrossRef]

59. Sharma, S.K.; Shukla, D.D.; Khatri, K.K.; Rajput, N.S. Performance evaluation of diesel engine using biodiesel fuel derived from waste cooking refined soyabean oil. Int. J. Mech. Prod. Eng. Res. Dev. 2017, 7, 103-110.

60. Hellmuth, D.N.M. Ceiba Pentandra-Sacred Tree for Classic Maya, National Tree for Guatemala Today; Flaar Mesoamerica: Mexico, 2011.

61. Jamaluddin, N.A.M. Techno-Economic Analysis and Physicochemical Properties of Ceiba Pentandra as a Second-Generation Biodiesel Based on ASTM D6751 and EN 14214. Bachelor Degree Thesis, University Tenaga Nasional, Selangor, Malaysia, 2017.

62. Riayatsyah, T.M.I.; Ong, H.C.; Chong, W.T.; Aditya, L.; Hermansyah, H.; Mahlia, T.M.I. Life cycle cost and sensitivity analysis of Reutealis trisperma as non-edible feedstock for future biodiesel production. Energies 2017, 10, 877. [CrossRef]

63. Ong, H.C.; Mahlia, T.M.I.; Masjuki, H.H.; Honnery, D. Life cycle cost and sensitivity analysis of palm biodiesel production. Fuel 2012, 98, 131-139. [CrossRef]

64. Howell, S. Time to take the biodiesel plunge? Render Mag. 2005, 1, 10-14.

65. Pagliaro, M.; Ciriminna, R.; Kimura, H.; Rossi, M.; Della Pina, C. From glycerol to value-added products. Angew. Chem. Int. Ed. 2007, 46, 4434-4440. [CrossRef]

66. Ong, H.C.; Masjuki, H.; Mahlia, T.; Silitonga, A.; Chong, W.; Leong, K. Optimization of biodiesel production and engine performance from high free fatty acid Calophyllum inophyllum oil in CI diesel engine. Energy Convers. Manag. 2014, 81, 30-40. [CrossRef] 
67. Silitonga, A.S.; Ong, H.C.; Mahlia, T.M.I.; Masjuki, H.H.; Chong, W.T. Characterization and production of Ceiba pentandra biodiesel and its blends. Fuel 2013, 108, 855-858. [CrossRef]

68. Silitonga, A.; Ong, H.; Masjuki, H.; Mahlia, T.; Chong, W.; Yusaf, T.F. Production of biodiesel from Sterculia foetida and its process optimization. Fuel 2013, 111, 478-484. [CrossRef]

(C) 2019 by the authors. Licensee MDPI, Basel, Switzerland. This article is an open access article distributed under the terms and conditions of the Creative Commons Attribution (CC BY) license (http://creativecommons.org/licenses/by/4.0/). 